\title{
AC 2009-684: MAPPING AN UNDERGRADUATE CURRICULUM ONTO THE ENVIRONMENTAL ENGINEERING BODY OF KNOWLEDGE
}

\section{Angela Bielefeldt, University of Colorado, Boulder}

Angela Bielefeldt is the Director of the Environmental Engineering Program at the University of Colorado at Boulder, and an Associate Professor in the Department of Civil, Environmental, \& Architectural Engineering. 


\title{
Mapping an Undergraduate Curriculum onto the Environmental Engineering Body of Knowledge
}

\begin{abstract}
In spring 2008 the American Academy of Environmental Engineers released a draft of the Body of Knowledge for Environmental Engineering (EnvE BOK). The BOK outlines the skills and abilities that are needed to become a licensed Professional Engineer, and describes which should be acquired as part of an accredited Bachelor's degree. The ABET-accredited EnvE B.S. curriculum at the University of Colorado at Boulder has been mapped onto the BOK outcomes and knowledge domains. Most topics are well covered, however multimedia breadth and the knowledge domain of systems analysis are not the main focus of any required courses because our curriculum was built primarily from existing courses in Civil, Chemical, and Mechanical engineering. The outcomes of project management and business knowledge are covered primarily in the capstone design course.
\end{abstract}

The BOK document may help inspire the next generation of Environmental Engineers. As such, it was discussed in the first year Introduction to EnvE course. The students in this course wrote an open-ended essay at the end of the semester to summarize their thoughts regarding EnvE. Themes that emerged from their 57 essays covered all of the outcome areas in the BOK, but some areas were discussed by more students than others. For example, $95 \%$ of all students mentioned science competency and water, but only $12 \%$ mentioned lifelong learning and 5\% uncertainty. The comparisons are interesting, as the students gathered these thoughts based on hearing five guest speakers who are practicing EnvEs and other activities in the course. It is noteworthy that $35 \%$ of the students stated that their sub-area of greatest interest was energy but the role of environmental engineers in solving the energy crisis was not emphasized in the draft BOK; the final BOK has expanded emphasis on energy. The opinions of practicing Environmental Engineers in regards to courses in our curriculum were provided in an annual alumni survey of former students 3 to 5 years after graduation. Areas of particular agreement with the EnvE BOK outcomes and knowledge domains are identified.

Overall, a big concern with the EnvE BOK is that it will be extremely resource intensive to document that all students graduating from a program have achieved the specified levels of competency for each of the 18 outcomes across the specified 16 knowledge domains. In light of this, it appears that the BOK is overly constrained. Due to the variety of career paths that students with Bachelor's degrees in EnvE may pursue, covering all possible topics that one might need to know in the B.S. degree seems unrealistic. Some students are turned off by the major due to over constraint that leads to a loss of flexibility in coursework. In addition, the most important topics that should be emphasized may be lost in such a long list of requirements. A better approach could be to develop critical thinking skills in our students and the ability to teach themselves during their professional careers in the context of life long learning.

\section{Background}

In spring 2008 the American Academy of Environmental Engineers (AAEE) released a draft of 
the Body of Knowledge for Environmental Engineering (EnvE BOK). ${ }^{1}$ The BOK was developed by a group of distinguished practicing environmental engineers and academics. This document outlines the skills and abilities that are needed to become a licensed Professional Engineer. It includes the skills and abilities that should be acquired as part of the accredited Bachelor's degree in Environmental Engineering. The document included 18 outcomes, which encompassed 15 knowledge domains and varying levels of achievement expected at the B.S. degree level. The levels of achievement are based on Daggett's Rigor/Relevance Framework ${ }^{2}$ and are defined as six cognitive levels and five situation levels (within discipline, across disciplines, complicated and complex situations). The document in general follows the model of the American Society of Civil Engineers (ASCE) BOK for Civil Engineering. ${ }^{3}$ However, the EnvE BOK document is more complex due to the addition of the knowledge domains and practical relevance levels.

The need for a BOK to guide the discipline is particularly relevant for licensure. In the past, the additional skills and knowledge that should be acquired after the ABET accredited B.S. degree and the Fundamentals of Engineering exam (FE) were not clearly defined. Thus, states could have significantly variable expectations for the requirements during the 4-year practical experience phase. In most states, this experience is documented and reviewed by state boards prior to approving an individual to sit for the Professional Engineers licensure exam (PE). B.S. degree programs have typically looked to ABET accreditation requirements ${ }^{4}$ to ensure that their programs are meeting minimum requirements. It is unclear how much of the BOK, which presents the "ideal", will eventually become accreditation requirements. This is of concern because of the significant assessment and tracking components that have become part of accreditation. Increases in the outcomes, knowledge domains, and achievement levels beyond current ABET requirements place additional assessment and documentation burdens on the accredited programs. In particular, it is not enough to show that these elements are included in required courses. Programs must produce documentation that students have actually learned this information and acquired these skills; the result of an outcome based system. Russell et al. ${ }^{5}$ note that the Civil Engineering BOK represents a long term direction for the profession, and over time more of its requirements could be explicitly reflected in accreditation requirements. It is assumed, therefore, that similar expectations would hold true for the EnvE BOK.

In January 2007 professors representing environmental engineering programs from across the U.S. met in Tempe, Arizona, to discuss whether a BOK for EnvE was needed and what it should contain. ${ }^{6}$ At this NSF-sponsored workshop there was significant disagreement in regards to the need for an EnvE BOK. Most present indicated that if an EnvE BOK were created that it should allow flexibility and not define the EnvE field too narrowly. These same ideas were echoed by the Association of Environmental Engineering and Science Professors (AEESP) in letter from the Board of Directors providing comments on the draft BOK. They note: "many members feel that one of the strengths of environmental engineering has been its flexibility and ability to adapt to established and emerging disciplines. Again, many worry that a prescriptive BOK would limit that unique attribute of our discipline. ... we see the outcome of the BOK as a guide, but not something that is prescriptive. [We feel that the BOK should] not represent or imply a prescriptive set of courses or topics." 7 After receiving comments, the final BOK was released in January 2009. ${ }^{8}$ Some changes are evident, including the fact that the 15 knowledge domains have now expanded to 16 due to the addition of technical communication (which is also 
professional outcome 14). A detailed discussion of comments that were received and how these were addressed in the final BOK has not yet been provided.

The history and current status of the EnvE professional is an important consideration for the development of a BOK. Historically, B.S. degrees in Civil, Chemical, or Mechanical Engineering were earned. These individuals then went on to specialize in environmental topics such as water, industrial waste, or air pollution. Licensure was obtained after the B.S. or M.S. degrees. Until 2000, a P.E. licensing examination specifically for environmental engineering was not available. However, individuals passing the P.E. licensing examination in environmental engineering may still have a traditional degree. Alternatively, about 50 programs now offer ABET-accredited B.S. degrees specifically in EnvE. ${ }^{10}$ Many of these degrees are offered from departments of Civil or Chemical Engineering. The courses that comprise the B.S. degree may come from a variety of different engineering and science majors, and therefore serve a role for multiple majors. A highly specific BOK for EnvE will make it more difficult for B.S. degree programs in EnvE to rely heavily on courses from other majors. In other cases courses may be specifically designed for an environmental engineering B.S. degree. It is also common that upper division courses are cross-listed as an upper-level undergraduate and lower level graduate courses. This accommodates students earning B.S. degrees specifically in EnvE and students entering an M.S. degree program with a B.S. degree from another major such as Civil or Mechanical Engineering.

It was of interest to critically review our B.S. EnvE degree curriculum in regards to the EnvE BOK. This is particularly important since our ABET-accredited degree was created as a multidisciplinary program and tasked with building our curriculum from existing courses in other majors rather than creating EnvE-specific courses. In this paper, our required courses are mapped onto the BOK to identify any gaps with respect to the outcomes or knowledge domains. It is also of interest to see how our students and alumni view EnvE in relation to the various knowledge domains, competencies, and skills identified in the BOK. Alumni of our program are now practicing environmental engineers and it is important to see if these professionals would comment on strengths or weaknesses of our program that map to the various competencies covered in the BOK. The goal is to identify which aspects of the BOK are most beneficial and identify concerns that represent potential improvements in our program.

\section{Methods}

A rough outline of the bachelor's degree curriculum in EnvE at the University of Colorado at Boulder (CU) is shown in Table 1. Note that some of the courses in the curriculum can be taken from multiple majors; for example, fluid mechanics can be taken as a Civil, Chemical, or Mechanical Engineering course. The learning objectives and contents of each of the courses in our curriculum have been documented fairly recently in the process of gathering data for ABET accreditation. Instructors in civil engineering rate the content of their courses in regards to the ABET A-K criteria, although this is only done at a crude level to indicate none, small, medium, or large coverage of the various outcomes. The instructors do not yet rate the expected level of achievement for the different criteria with respect to Bloom's taxonomy or Daggett's Rigor/Relevance Framework. Recently, students have begun self-assess their learning gains in selected civil engineering courses against the ABET A-K criteria at the end of the semester via 
the Faculty/Course Questionnaire (FCQ). Students rate how much the course contributed to their understanding of each area on a scale from 1 to 6 or not applicable. Again, this does not directly correlate to levels of knowledge. Eventually we hope to extend these student assessments to all of our courses, and add EnvE specific criteria. Example results from these mapping exercises will be presented in the Results section of this paper. Other majors that offer courses which comprise the EnvE curriculum have different course assessment approaches. This makes unifying the data into a single evaluation for our EnvE program very challenging.

Examples of student work from the courses can be examined to determine the level of achievement of the various outcomes. This examination should conducted as an unbiased review by outside faculty, such as through a curriculum committee, or via an external professional advisory board (PAB). Our EnvE program will pilot this process using one of our courses and a few example criteria at the spring PAB meeting. Multiple student work examples will need to be examined and the feedback from multiple reviewers compared, due to expected differences in opinion. This will be an extensive effort given to the detailed requirements in the EnvE BOK. Because the EnvE program draws courses from different majors, each course would not only need to document learning outcomes for its own student majors (such as civil engineering) but also the EnvE outcomes for EnvE majors. This will create significant extra work and it is unclear how much of this effort our PAB will be willing to take on.

Table 1. Courses in the EnvE Curriculum at CU. The courses are 3 credits unless noted by the alternative number of credits in brackets. Superscripts denote the contributing majors that offer each course: $\mathrm{CV}, \mathrm{CH}, \mathrm{MC}$ for civil, chemical, and mechanical engineering, respectively.

\begin{tabular}{|c|c|c|}
\hline & Fall Semester & Spring Semester \\
\hline First year & $\begin{array}{l}\text { Chemistry for Engineers + Lab [5] } \\
\text { Calculus } 1 \text { [4] } \\
\text { Engineering Computing } \\
\text { Introduction to EnvE [1 credit] } \\
\text { H\&SS elective }\end{array}$ & $\begin{array}{l}\text { Physics } 1[4] \\
\text { Calculus } 2[4] \\
\text { First year Engineering Projects } \\
\text { Technical Elective w/ Earth Science focus } \\
\text { H\&SS elective }\end{array}$ \\
\hline $\begin{array}{l}\text { Second } \\
\text { year }\end{array}$ & $\begin{array}{l}\text { Physics } 2[4]+\text { Experimental Phys [1] } \\
\text { Calculus } 3 \text { [4] } \\
\text { Fundamentals of EnvE }{ }^{\mathrm{CV}} \\
\text { H\&SS elective }\end{array}$ & $\begin{array}{l}\text { Physical Chemistry for Engrs } \\
\text { Linear Algebra + Differential Eqns [4] } \\
\text { Statics CV,MC } \\
\text { Material \& Energy Balances }{ }^{\mathrm{CH}} \\
\text { H\&SS elective }\end{array}$ \\
\hline $\begin{array}{l}\text { Third } \\
\text { year }\end{array}$ & $\begin{array}{l}\text { Water Chemistry with Lab [4] }{ }^{\mathrm{CV}} \\
\text { Engineering Economics } \mathrm{CV} \\
\text { Fluid Mechanics CV, CH, MC } \\
\text { Thermodynamics } \mathrm{CV}, \mathrm{CH}, \mathrm{MC} \\
\text { Upper level Writing course }\end{array}$ & $\begin{array}{l}\text { Environmental Organic Chemistry }{ }^{\mathrm{CV}} \\
\text { Probability and Statistics } \mathrm{CV}, \mathrm{CH} \\
\text { Heat Transfer } \mathrm{CH}_{\mathrm{MC}} \\
\text { Air Pollution Control }{ }_{\mathrm{MC}} \\
\text { Intro to Environmental Microbiology } \mathrm{CV}\end{array}$ \\
\hline $\begin{array}{l}\text { Fourth } \\
\text { year }\end{array}$ & $\begin{array}{l}\text { Environmental Engrg Processes } \\
\text { Option Course } \\
\text { Option Course } \\
\text { Technical elective } \\
\text { Technical elective } \\
\text { H\&SS elective }\end{array}$ & $\begin{array}{l}\text { Environmental Engineering Design }{ }^{\mathrm{CV}} \\
\text { Engineering Hydrology } \mathrm{CV} \\
\text { Air/Earth Lab/Field course } \\
\text { Option course } \\
\text { Technical elective }\end{array}$ \\
\hline
\end{tabular}


Beyond a simple mapping exercise, we were interested in determining if our students and alumni would agree with the EnvE BOK requirements. Although specific feedback on the BOK has not been solicited, we have existing feedback from current students, graduating seniors and alumni that may provide insight into this topic. An on-line survey is used to solicit feedback from former students 3 to 5 years after graduation. The survey has been distributed since 2005 . In some cases, current contact information for the alumni is not available. Our program has been relatively small and therefore the number of responses is also small, totaling 38 . In one part of the survey the alumni are asked to write in courses that were most important and least important for their professional field, and any deficiencies or recommendations for improvement in the curriculum. These are open ended questions and ask the alumni to think back many years. So anything that stands out in their minds enough to write about is probably worth noting. The curriculum has gone through some changes since many of these professionals were students, so some of the deficiencies or least helpful classes that they noted have since been changed. These changes have often been driven directly by their feedback. In addition, alumni review our EnvE program objectives and rate on a 1 to 5 Likert scale $(1=$ very low; $3=$ moderate; $5=$ extremely high) the extent to which the objectives are appropriate and important for EnvE and the extent to which our program at the University of Colorado at Boulder actually met these educational objectives for the individual. Our program criteria will be mapped to current ABET and the $\mathrm{BOK}$ and the results from the alumni feedback on our curriculum presented in the Results section.

The EnvE BOK may help to inspire and guide the next generation of Environmental Engineers. It also helps to define EnvE as a distinct discipline, which is helpful for students struggling to determine what EnvE is and if they are interested in it as a career. As such, the draft EnvE BOK ${ }^{1}$ was distributed in the freshman-level Introduction to EnvE course. The goal of the first year course is to accurately convey to the students what EnvE is, what skills are needed, and what EnvEs do on the job. The course is 1-credit so it meets for 50-minutes once per week. The students complete a variety of assignments over the semester to help increase their knowledge of EnvE and self-reflect on how EnvE matches their personal career aspirations. The first assignment is a short exercise to identify EnvE sub-discipline areas, state their own area(s) of greatest interest, and identify an employer in this area and a project they have worked on using the Web as a resource. Students could use the BOK to help them define EnvE and answer other questions on this assignment. Later in Homework 4 the students plot out a course plan to graduation that meets the requirements for the EnvE B.S. degree at the University of Colorado at Boulder. The student then mapped these courses in their 4-year EnvE degree plan onto the ABET criteria for engineering and program-specific criteria for EVEN. This indicated if the coverage of the required content in our curriculum was obvious to the students or not. 
Finally, it was of interest to see if the students in the first year course would comment on various aspects of the EnvE profession that are emphasized or not in the BOK in a final reflective essay. At the end of the semester the students write a reflection on what they learned from the guest speakers. In 2008 the course included one research professor working on energy issues and four alumni from the University of Colorado at Boulder (CU) who are working professionals in EnvE. These alumni have either a BS or MS from CU. They work in various sub-specialty areas for the US EPA, large and small consulting firms in the local area, and one is self-employed. One of the questions on that homework assignment asked the students to list three ABET skills that the speakers used most often in their jobs. This review was followed by open-ended essays asking the students to personally define EnvE, comment on aspects of the profession that they find personally appealing and not, and whether or not they want to pursue a degree in EnvE. The themes that the students associated with EnvE that rose to the top of their minds when writing a 2-page essay may indicate the elements that are most and least attractive of our profession.

\section{Results and Discussion}

\section{Courses Mapped to BOK Outcomes}

For the EnvE BOK outcomes that correspond directly to ABET outcomes, mapping of courses that cover each area is fairly simple. In particular, in Civil Engineering instructors for each course describe how it relates to the ABET A-K criteria by ranking the coverage of course content as large, medium, small, or not applicable (L, M, S, or N/A, respectively). Examples of these course ratings taken from our previous ABET self-study are shown in Table 2. For some outcomes, many courses strongly contribute to achieving the outcome, such as criteria A (math, science, and engineering) and $\mathrm{E}$ (engineering problem solving). Other criteria are covered in far fewer courses and/or to a much smaller extent, such as life-long learning. This diversity seems appropriate. Not every criterion is of equal importance, nor is it appropriate or reasonable for all elements to be included in all courses.

Table 2. Example of Civil Engineering courses mapped to ABET A-K Outcomes

\begin{tabular}{|l|c|c|c|c|c|c|c|c|c|c|c|}
\hline $\begin{array}{l}\text { ABET outcome: } \\
\text { Courses }\end{array}$ & $\mathrm{A}$ & $\mathrm{B}$ & $\mathrm{C}$ & $\mathrm{D}$ & $\mathrm{E}$ & $\mathrm{F}$ & $\mathrm{G}$ & $\mathrm{H}$ & $\mathrm{I}$ & $\mathrm{J}$ & $\mathrm{K}$ \\
\hline Intro EnvE & $\mathrm{M}$ & $\mathrm{S}$ & $\mathrm{N} / \mathrm{A}$ & $\mathrm{S}$ & $\mathrm{M}$ & $\mathrm{M}$ & $\mathrm{N} / \mathrm{A}$ & $\mathrm{S}$ & $\mathrm{S}$ & $\mathrm{S}$ & $\mathrm{S}$ \\
\hline Thermodynamics & $\mathrm{L}$ & $\mathrm{S}$ & $\mathrm{S}$ & $\mathrm{N} / \mathrm{A}$ & $\mathrm{L}$ & $\mathrm{N} / \mathrm{A}$ & $\mathrm{N} / \mathrm{A}$ & $\mathrm{N} / \mathrm{A}$ & $\mathrm{N} / \mathrm{A}$ & $\mathrm{S}$ & $\mathrm{S}$ \\
\hline Statics & $\mathrm{L}$ & $\mathrm{S}$ & $\mathrm{S}$ & $\mathrm{S}$ & $\mathrm{L}$ & $\mathrm{N} / \mathrm{A}$ & $\mathrm{S}$ & $\mathrm{N} / \mathrm{A}$ & $\mathrm{N} / \mathrm{A}$ & $\mathrm{N} / \mathrm{A}$ & $\mathrm{L}$ \\
\hline Fluids & $\mathrm{L}$ & $\mathrm{M}$ & $\mathrm{S}$ & $\mathrm{S}$ & $\mathrm{L}$ & $\mathrm{S}$ & $\mathrm{L}$ & $\mathrm{S}$ & $\mathrm{S}$ & $\mathrm{S}$ & $\mathrm{M}$ \\
\hline Prob/Statistics & $\mathrm{L}$ & $\mathrm{S}$ & $\mathrm{N} / \mathrm{A}$ & $\mathrm{N} / \mathrm{A}$ & $\mathrm{S}$ & $\mathrm{N} / \mathrm{A}$ & $\mathrm{N} / \mathrm{A}$ & $\mathrm{S}$ & $\mathrm{N} / \mathrm{A}$ & $\mathrm{N} / \mathrm{A}$ & $\mathrm{S}$ \\
\hline Fund EnvE & $\mathrm{L}$ & $\mathrm{N} / \mathrm{A}$ & $\mathrm{N} / \mathrm{A}$ & $\mathrm{M}$ & $\mathrm{L}$ & $\mathrm{S}$ & $\mathrm{M}$ & $\mathrm{L}$ & $\mathrm{L}$ & $\mathrm{L}$ & $\mathrm{L}$ \\
\hline Water Chemistry & $\mathrm{L}$ & $\mathrm{L}$ & $\mathrm{S}$ & $\mathrm{L}$ & $\mathrm{L}$ & $\mathrm{S}$ & $\mathrm{L}$ & $\mathrm{S}$ & $\mathrm{N} / \mathrm{A}$ & $\mathrm{M}$ & $\mathrm{M}$ \\
\hline Hydrology & $\mathrm{L}$ & $\mathrm{N} / \mathrm{A}$ & $\mathrm{M}$ & $\mathrm{M}$ & $\mathrm{L}$ & $\mathrm{S}$ & $\mathrm{M}$ & $\mathrm{M}$ & $\mathrm{S}$ & $\mathrm{M}$ & $\mathrm{M}$ \\
\hline EnvE Design & $\mathrm{M}$ & $\mathrm{S}$ & $\mathrm{L}$ & $\mathrm{L}$ & $\mathrm{M}$ & $\mathrm{M}$ & $\mathrm{L}$ & $\mathrm{M}$ & $\mathrm{S}$ & $\mathrm{M}$ & $\mathrm{M}$ \\
\hline
\end{tabular}

As Table 2 illustrates, different courses are targeted to achieve a variety of outcomes at varying levels. The old system could be adapted in order to map each outcome to a level of achievement rather than merely topic coverage. For example, it may be possible that an instructor could rate 
their coverage of an outcome topic as "large" due to the requirement to define a large number of terms rather than apply knowledge to analyze and solve a complex problem appropriate to environmental engineering.

In the future the additional EnvE BOK outcomes can be added to this matrix. However, it may be difficult to get full buy-in for EnvE because our curriculum is comprised of courses from other majors that may/may not be taught by EnvE faculty. While the civil engineering faculty will probably be willing to rate their courses against the criteria using Bloom's taxonomy for levels of achievement due to the requirements of the Civil Engineering $\mathrm{BOK}^{3}$, extending this to the EnvE criteria and Daggett's achievement levels will require extra effort. Our faculty would need to be educated on the levels of achievement rating system. For faculty and courses outside of Civil Engineering that are not facing BOK requirements this level of effort from the faculty is likely an unreasonable expectation. Examples of new faculty ratings to these extended EnvE BOK outcomes criteria are shown in Table 3, but we are still using the old rating system rather than requiring faculty to look to achievement levels.

Table 3. Example of faculty and student ratings for selected courses mapped to the EnvE BOK outcomes

\begin{tabular}{|l|c|c|c|c|c|c|}
\hline & \multicolumn{3}{|c|}{ Instructor Ratings } & \multicolumn{2}{c|}{ Average Student Ratings } \\
\hline EnvE BOK Outcome & $\begin{array}{c}\text { Hydraul } \\
\text {-ics }\end{array}$ & $\begin{array}{c}\text { Ground } \\
\text { Water }\end{array}$ & $\begin{array}{c}\text { EnvE } \\
\text { Design }\end{array}$ & $\begin{array}{c}\text { EnvE } \\
\text { Design }\end{array}$ & $\begin{array}{c}\text { Intro } \\
\text { EnvE }\end{array}$ & $\begin{array}{c}\text { Fund. } \\
\text { EnvE }\end{array}$ \\
\hline 1. Math \& science knowledge & $\mathrm{M}$ & $\mathrm{M}$ & $\mathrm{M}$ & 3.9 & 4.0 & 4.1 \\
\hline 2. Design/conduct experiments & $\mathrm{M}$ & $\mathrm{S}$ & $\mathrm{S}$ & 3.2 & 3.9 & 3.1 \\
\hline 3. Modern engineering tools & $\mathrm{M}$ & $\mathrm{M}$ & $\mathrm{M}$ & 4.7 & 3.9 & 3.5 \\
\hline 4. In-depth competence & $\mathrm{M}$ & $\mathrm{M}$ & $\mathrm{M}$ & $\mathrm{NR}$ & $\mathrm{NR}$ & $\mathrm{NR}$ \\
\hline 5. Risk, reliability, uncertainty & $\mathrm{N} / \mathrm{A}$ & $\mathrm{S}$ & $\mathrm{M}$ & $\mathrm{NR}$ & $\mathrm{NR}$ & $\mathrm{NR}$ \\
\hline $\begin{array}{l}\text { 6. Problem formulation and } \\
\text { conceptual analysis }\end{array}$ & $\mathrm{M}$ & $\mathrm{L}$ & $\mathrm{M}$ & 4.0 & 4.4 & 4.0 \\
\hline 7. Creative Design & $\mathrm{L}$ & $\mathrm{L}$ & $\mathrm{L}$ & 5.1 & 3.7 & 3.6 \\
\hline 8. Sustainability * & $\mathrm{S}$ & $\mathrm{M}$ & $\mathrm{M}$ & 4.5 & 4.7 & 4.3 \\
\hline 9. Multimedia breadth/ interaction & $\mathrm{S}$ & $\mathrm{M}$ & $\mathrm{M}$ & $\mathrm{NR}$ & 4.2 & $\mathrm{NR}$ \\
\hline 10. Societal impact & $\mathrm{S}$ & $\mathrm{M}$ & $\mathrm{M}$ & 3.9 & 4.9 & 4.7 \\
\hline 11. Contemporary Global Issues & $\mathrm{N} / \mathrm{A}$ & $\mathrm{S}$ & $\mathrm{M}$ & 3.4 & 4.5 & 4.4 \\
\hline 12. Teamwork & $\mathrm{S}$ & $\mathrm{S}$ & $\mathrm{L}$ & 5.1 & 4.9 & 3.0 \\
\hline 13. Prof /ethical responsibilities & $\mathrm{S}$ & $\mathrm{S}$ & $\mathrm{S}$ & 3.3 & 5.1 & 3.8 \\
\hline 14. Communication & $\mathrm{S}$ & $\mathrm{S}$ & $\mathrm{L}$ & 3.5 & 3.0 & 1.6 \\
\hline 15. Lifelong learning & $\mathrm{N} / \mathrm{A}$ & $\mathrm{S}$ & $\mathrm{S}$ & 3.5 & 4.7 & 3.5 \\
\hline 16. Project management & $\mathrm{S}$ & $\mathrm{S}$ & $\mathrm{S}$ & 4.9 & $\mathrm{NR}$ & 2.4 \\
\hline 17. Business \& public admin. & $\mathrm{S}$ & $\mathrm{S}$ & $\mathrm{S}$ & 3.9 & $\mathrm{NR}$ & 3.2 \\
\hline 18. Leadership & $\mathrm{S}$ & $\mathrm{S}$ & $\mathrm{S}$ & 4.0 & $\mathrm{NR}$ & 2.8 \\
\hline NR & & & & & & \\
\hline
\end{tabular}

$\mathrm{NR}=$ not rated since not on the FCQ;

* students rated this in the context of constraints on design included sustainability and economics

Students at the end of the semester are asked to rate the courses using written surveys (currently implemented as supplemental questions on the Faculty Course Questionnaires, FCQs). Students rate if the course improved their understanding of various criteria using a scale of 1 to 6 or not 
applicable. Examples of these ratings are shown in Table 3. Students have not yet rated all courses, as this rating exercise was only piloted on selected courses in Civil Engineering. The not applicable ratings were averaged into the scores as a zero. Students do vary their ratings somewhat, although self-assessments of learning are of questionable value. The goal is for the student feedback to be used as a logic check on faculty claims in order to indicate potential disconnects. These areas will then be targeted for specific review of student work and/or discussions with the faculty on whether the learning objectives were being achieved. Because course learning outcomes may vary when different instructors teach courses, reliable expectations for the curriculum would be set using the lowest common ratings of the various instructors. An additional limitation of this system is again the complications with EnvE specific expectations for courses are offered from the various departments outside of EnvE. It isn't easy to get the departments to add EnvE specific questions to their course FCQs. They use the available optional questions for their own program evaluation, such as Civil Engineering.

Using information from the course materials gathered for our previous ABET review and personal knowledge of some courses, Table 4 summarizes how our courses map to the EnvE BOK outcomes. This is not intended to be an exhaustive list of courses, but rather show a few examples. It was easy to identify numerous required courses in the curriculum that cover the ABET-related outcomes. In-depth competence is achieved for each student in at least the area that they select for their specialization option: air quality, ecology, chemical processing, energy, remediation, or water. For each option area the students' select three courses (nine credits) from among a list (http://www.colorado.edu/engineering/even/evenbs.htm). Only a few selected examples of how these courses map to the EnvE outcomes have been shown. Some of the outcomes requirements in the EnvE BOK that are outside of the current ABET criteria are not emphasized in our curriculum; for example: project management, business and public administration, and leadership.

Mapping courses in our curriculum to the knowledge domains is largely trivial due to the ease of recognizing the domains in the course titles from Table 1 (calculus maps to math, etc.). Systems Analysis and Business Management are the only two knowledge areas that aren't obvious.

Table 4. EnvE BOK Outcomes with associated courses and knowledge domains

\begin{tabular}{|l|c|l|}
\hline $\begin{array}{l}\text { EnvE BOK } \\
\text { Outcome }\end{array}$ & Primary Course Examples & \multicolumn{1}{c|}{$\begin{array}{c}\text { Option Course } \\
\text { Examples }\end{array}$} \\
\hline $\begin{array}{l}\text { 1. Basic math \& } \\
\text { science knowledge }\end{array}$ & $\begin{array}{c}\text { Calculus 1, 2, and 3; LinAlg+Diff Eqns } \\
\text { Chemistry, Physics, Microbiology, Matl \& E } \\
\text { Balances, Fluids, Earth Sci Tech Elective }\end{array}$ & $\begin{array}{l}\text { Principles of Ecology } \\
\text { W/WW treatment }\end{array}$ \\
\hline $\begin{array}{l}\text { 2. Design and } \\
\text { conduct experiments }\end{array}$ & $\begin{array}{c}\text { Chemistry Lab, Physics Lab, Water Quality } \\
\text { Lab, Air/Earth Lab/Field course, Fluids, } \\
\text { Thermodynamics, Statics }\end{array}$ & $\begin{array}{l}\text { Intro Applied Ecology } \\
\text { Env Field Geochem. } \\
\text { Physical Chem Lab }\end{array}$ \\
\hline $\begin{array}{l}\text { 3. Use of modern } \\
\text { engineering tools }\end{array}$ & $\begin{array}{c}\text { Engineering computing; Water Quality Lab } \\
\text { Air/Earth lab/field course }\end{array}$ & $\begin{array}{l}\text { Intro Applied Ecology } \\
\text { Env Sampling/Analy }\end{array}$ \\
\hline $\begin{array}{l}\text { 4. In-depth } \\
\text { competence }\end{array}$ & Option courses & $\begin{array}{l}\text { Probability \& Statistics } \\
\text { 5. Risk, reliability, } \\
\text { uncertainty }\end{array}$ \\
\hline
\end{tabular}




\begin{tabular}{|l|c|l|}
\hline $\begin{array}{l}\text { 6. Problem } \\
\text { formulation and } \\
\text { conceptual analysis }\end{array}$ & $\begin{array}{c}\text { Thermodynamics; Fluids; Statics; Heat } \\
\text { Transfer; Fundamentals EnvE; Hydrology; } \\
\text { EnvE Processes }\end{array}$ & $\begin{array}{l}\text { W/WW treatment } \\
\text { Hydraulics } \\
\text { Hazardous Waste }\end{array}$ \\
\hline $\begin{array}{l}\text { 7. Creative } \\
\text { Design }\end{array}$ & $\begin{array}{c}\text { First year projects } \\
\text { EnvE Design }\end{array}$ & $\begin{array}{l}\text { Hazardous Waste } \\
\text { W/WW tmt }\end{array}$ \\
\hline 8. Sustainability & Fundamentals EnvE; EnvE Design & Sustainable Energy \\
\hline $\begin{array}{l}\text { 9. Multimedia } \\
\text { breadth/interaction }\end{array}$ & $\begin{array}{c}\text { Fundamentals EnvE; Env Organic Chemistry } \\
\text { Air Pollution; Water Chemistry; Hydrology; } \\
\text { Air/Earth lab/field }\end{array}$ & $\begin{array}{l}\text { Hazardous Waste } \\
\text { Environm. Modeling }\end{array}$ \\
\hline $\begin{array}{l}\text { 10. Societal impact } \\
\text { Global Issues }\end{array}$ & $\begin{array}{c}\text { H\&SS electives; Intro EnvE } \\
\text { Fundamentals EnvE }\end{array}$ & Hazardous Waste \\
\hline $\begin{array}{l}\text { 11. Teamwork } \\
\text { Fundamentals EnvE }\end{array}$ & $\begin{array}{l}\text { W/WW treatment } \\
\text { Renewable Energy Pol. }\end{array}$ \\
\hline $\begin{array}{l}\text { 13. Professional and } \\
\text { ethical issues }\end{array}$ & $\begin{array}{c}\text { Intro EnvE; First year projects; } \\
\text { Water Chemistry; EnvE Design }\end{array}$ & $\begin{array}{l}\text { Intro Applied Ecology } \\
\text { EnvE Sampling/ Analy }\end{array}$ \\
\hline $\begin{array}{l}\text { 14. Communication } \\
\text { Intro to EnvE } \\
\text { EnvE Design }\end{array}$ & Upper level writing course; & Hazardous Waste \\
\hline $\begin{array}{l}\text { 15. Lifelong learning } \\
\text { management }\end{array}$ & Water Chemistry Lab; EnvE Design \\
\hline $\begin{array}{l}\text { 17. Business and } \\
\text { public administration }\end{array}$ & EnvE Design & \\
\hline 18. Leadership & EnvE Design & \\
\hline
\end{tabular}

\section{Program Objectives Mapped to ABET and BOK Outcomes}

The program objectives for the EnvE curriculum at the University of Colorado at Boulder (CU) were developed with input from a professional advisory panel and a view to the ABET requirements. These were somewhat loosely translated into a variety of questions on the alumni survey. Abbreviated descriptions of these objectives are listed in Table 5 below. The CU program objectives that our alumni rated as most important are listed first. Specifically, alumni were asked to rate the extent that each is an appropriate and important educational objective for Environmental Engineering on a scale from $5=$ extremely high to $1=$ very low. The related ABET Criterion 3 outcomes, the so-called A to K criteria, which are common to all engineering majors are shown in relation to the CU program objectives. The ABET program-specific criteria for EnvE are established by the AAEE. These requirements for EnvE are already somewhat more restrictive than the program-specific criteria for many other majors. These ABET program specific criteria for EnvE already incorporate many of the knowledge domain areas described in the EnvE BOK. The curriculum at CU covers all of the ABET requirements for EnvE. The mapping exercise of the EnvE BOK outcomes to the CU program objectives was somewhat more difficult. Most outcomes are readily covered. BOK Outcome 4, in-depth knowledge, is encompassed in our curriculum by the specialization option that each student selects. 
Table 5. CU Alumni Importance Ratings of the University of Colorado Program Objectives and related ABET and EnvE BOK requirements

\begin{tabular}{|c|c|c|c|}
\hline CU Program Objective Topic & $\begin{array}{l}\text { Related EnvE BOK } \\
\text { Outcomes }\end{array}$ & $\begin{array}{l}\text { Related } \\
\text { ABET } \\
\text { outcomes }\end{array}$ & $\begin{array}{l}\text { Avg } \pm \text { Std } \\
\text { Dev. of } \\
\text { Alumni } \\
\text { Survey } \\
\text { Importance } \\
\text { Rating }\end{array}$ \\
\hline Communication * & 14. Communication & $3 g$ & $4.80 \pm 0.56$ \\
\hline Design process $*$ & $\begin{array}{l}\text { 7. Creative Design; } 6 \text {. Problem } \\
\text { formulation; } 16 \text {. Project management; } \\
\text { 8. Sustainability }\end{array}$ & 3c; EnvE & $4.67 \pm 0.62$ \\
\hline $\begin{array}{l}\text { Proficiency in the sciences, } \\
\text { mathematics, and engineering }\end{array}$ & $\begin{array}{l}\text { 1. Basic math \& science } \\
\text { knowledge }\end{array}$ & $\begin{array}{l}\text { 3a, 3e; } \\
\text { EnvE }\end{array}$ & $4.55 \pm 0.52$ \\
\hline Team work $*$ & 12. Teamwork & $3 \mathrm{~d}$ & $4.53 \pm 0.74$ \\
\hline $\begin{array}{l}\text { Apply multidisciplinary } \\
\text { approaches in data-poor situations } \\
\text { to develop solutions for } \\
\text { environmental problems } *\end{array}$ & $\begin{array}{l}\text { 9. Multimedia breadth/interaction } \\
\text { 5. Risk, reliability, uncertainty } \\
\text { 6. Problem formulation }\end{array}$ & $3 e$ & $4.50 \pm 0.64$ \\
\hline $\begin{array}{l}\text { Instill a responsibility to serve the } \\
\text { needs of society and protect the } \\
\text { planet in an ethical manner }\end{array}$ & $\begin{array}{l}\text { 10. Societal impact; } \\
\text { 8. Sustainability; } 13 \text {. Professional } \\
\text { \& ethical responsibilities }\end{array}$ & $3 \mathrm{f}, 3 \mathrm{~h}, 3 \mathrm{j}$ & $4.49 \pm 0.99$ \\
\hline Life-long learning & 15. Lifelong learning & $3 \mathrm{i}$ & $4.48 \pm 0.83$ \\
\hline $\begin{array}{l}\text { Integrates research to develop } \\
\text { independence and communication } \\
\text { skills }\end{array}$ & $\begin{array}{l}\text { 2. Design and conduct experiments } \\
\text { 3. Modern engineering tools; } \\
\text { 14. Communication; } \\
\text { 18. Leadership }\end{array}$ & $3 \mathrm{~b} ; 3 \mathrm{~g} ; 3 \mathrm{k}$ & $4.44 \pm 0.63$ \\
\hline $\begin{array}{l}\text { Changing nature of preparation } \\
\text { required }\end{array}$ & 15. Lifelong learning & $3 \mathrm{i}, 3 \mathrm{j}$ & $4.44 \pm 0.63$ \\
\hline Field learning experiences * & $\begin{array}{l}\text { 2. Design \& conduct experiments; } \\
\text { 3. Modern engineering tools }\end{array}$ & $3 \mathrm{~b} ; 3 \mathrm{k}$ & $4.33 \pm 0.82$ \\
\hline $\begin{array}{l}\text { Prepare to ethically cope with the } \\
\text { challenges and ambiguities of } \\
\text { environmental problems, which } \\
\text { involve competing technical, } \\
\text { economic, and social goals * }\end{array}$ & $\begin{array}{l}\text { 5. Risk, reliability, uncertainty } \\
\text { 6. Problem formulation } \\
\text { 10. Societal impact } \\
\text { 13. Professional and ethical } \\
\text { responsibilities }\end{array}$ & $\begin{array}{l}\text { 3f; 3h; 3c; } \\
\text { 3e; EnvE }\end{array}$ & $4.33 \pm 0.90$ \\
\hline Computer learning experiences & 3. Modern engineering tools & $3 \mathrm{k}$ & $4.13 \pm 0.74$ \\
\hline Laboratory learning experiences * & $\begin{array}{l}\text { 2. Design \& conduct experiments; } \\
\text { 3. Modern engineering tools }\end{array}$ & $3 \mathrm{~b} ; 3 \mathrm{k}$ & $4.00 \pm 0.85$ \\
\hline \multirow[t]{2}{*}{ Arts and humanities } & $\begin{array}{l}\text { 10. Societal impact } \\
\text { 11. Contemporary Global Issues }\end{array}$ & $3 \mathrm{~h}$ & $3.87 \pm 1.19$ \\
\hline & 17. Business \& public administration & & NR \\
\hline (specialization option) & 4. In-depth competence & & NR \\
\hline
\end{tabular}

* some of these questions were combined on the 2007 alumni surveys, so their data was not included since it reflected the combined importance of multiple factors; therefore only 15 alumni responses have been averaged for questions with *; $\mathrm{NR}=$ not rated

The BOK outcomes 8, 9, 11, 16, 17, and 18 are less directly apparent in the CU objectives. BOK Outcome 8 on sustainability is covered in the context of our design course and protecting the planet in an ethical manner. BOK Outcome 9, multimedia breadth and interactions, is not readily 
apparent in our program objectives. However, multimedia breadth is covered by the required courses in our curriculum that include air, water, earth science, and biology. The most closely related program objective is our "multi-disciplinary approaches"; however, multi-media interactions should probably be acknowledged more directly. Because our curriculum was built from existing courses in civil, chemical, and mechanical engineering, a single course that focuses on multimedia interactions is not required. Electives in Environmental Modeling and Hazardous \& Industrial Waste Management do focus on this topic. BOK Outcome 11, globalization and other contemporary issues, are incorporated into a variety of courses but is not the subject of a stand-alone course in our curriculum. The current program objectives were developed by our faculty and professional advisory board. Changes would need to be made to fully embrace the EnvE BOK.

Table 5 includes the average importance rating that the alumni gave the various areas. Due to changes in the survey over time, the values represent an average of either 24 alumni responses to the 2007 and 2008 surveys or the 15 responses to the 2008 survey. The alumni rate the importance of almost all of the program objective areas as high (4) to extremely high (5). Expanding the list of objectives further may expand the number of highly rated items. But these outcomes may be lost within an also extensive list of knowledge domain requirements. These are discussed in more detail below.

The key areas that we don't ask our alumni about are BOK Outcomes 16, 17, and 18. Project management ideas are included in the capstone design course. Each team has a project manager, and the course simulates a consulting firm where the students write a proposal in response to an RFP, followed by a Work Plan for the semester, as they execute the tasks associated with an alternatives comparison and pre-design. The capstone design course also incorporates the various regulatory constraints on the process and they meet with their clients, so students become familiar with the business and public administration aspects of EnvE. The project manager is generally also the team leader, so leadership is addressed in that manner. However, alumni are not asked about the importance of these areas and their preparation for them.

\section{Alumni and First Year Student Perspectives on the EnvE BOK Outcomes}

The alumni survey write-in responses stating the most beneficial courses, least beneficial courses, and recommended improvements to the curriculum were classified into the various EnvE BOK outcome areas. Although 38 alumni responded to the survey in 2005 to 2008, only 31 wrote in comments. These can include more than one course or aspect in each area, or none. Responses are summarized in Table 6; blanks indicate that no write-in comments pertained to this area. The write-in comments are believed to be particularly important, because it required time on the part of the individual to reflect back three to five years on the best and worst aspects of their curriculum and note any stand-outs. However, these may be driven by the quality of the course specific to our University rather than the importance of the content to the EnvE profession. Standouts of importance include the senior design experience, the fundamental sophomore/junior EnvE course, water chemistry laboratory, and communication course. The design course incorporates 17 of the EnvE BOK outcomes (only lacking \#2, design and conduct experiments) in a real-world project setting, which could account for its popularity. All of the outcome areas may therefore be important to our alumni. 'Modern engineering tools' appears to 
be a weakness of our program and more emphasis should be placed on communication due to its huge importance.

Table 6. Summary of First Year Students and Alumni Comments Related to BOK Outcomes

\begin{tabular}{|c|c|c|c|c|}
\hline \multirow[t]{2}{*}{$\begin{array}{l}\text { EnvE BOK } \\
\text { Outcome }\end{array}$} & \multirow{2}{*}{$\begin{array}{l}\% \text { first } \\
\text { year } \\
\text { student } \\
\text { essays }\end{array}$} & \multicolumn{3}{|c|}{$\begin{array}{l}\text { Alumni Survey Write-In Comments, \# individuals: related } \\
\text { courses or information }\end{array}$} \\
\hline & & Most beneficial & $\begin{array}{l}\text { Least } \\
\text { Beneficial }\end{array}$ & $\begin{array}{l}\text { Recommended } \\
\text { improvement }\end{array}$ \\
\hline $\begin{array}{l}\text { 1. Basic math \& } \\
\text { science knowledge }\end{array}$ & $\begin{array}{l}81 \% \\
95 \%\end{array}$ & $\begin{array}{l}9 \text { basic EnvE } \\
\text { course }\end{array}$ & & \\
\hline $\begin{array}{l}\text { 2. Design and } \\
\text { conduct experiments }\end{array}$ & $47 \%$ & $\begin{array}{l}8 \text { water chemistry } \\
\text { lab }\end{array}$ & & \\
\hline $\begin{array}{l}\text { 3. Modern } \\
\text { engineering tools }\end{array}$ & $\begin{array}{l}32 \% \\
\text { computers }\end{array}$ & & $\begin{array}{l}6 \\
\text { computing }\end{array}$ & $\begin{array}{l}\text { 3: more computing } \\
\text { needed; } \\
\text { 4: CAD \& } 2 \text { GIS should } \\
\text { be required }\end{array}$ \\
\hline $\begin{array}{l}\text { 4. In-depth } \\
\text { competence }\end{array}$ & & & & \\
\hline $\begin{array}{l}\text { 5. Risk, reliability, } \\
\text { uncertainty }\end{array}$ & $\begin{array}{c}16 \% \\
5 \%\end{array}$ & & & \\
\hline $\begin{array}{l}\text { 6. Problem } \\
\text { formulation }\end{array}$ & $51 \%$ & & & \\
\hline $\begin{array}{l}\text { 7. Creative } \\
\text { Design }\end{array}$ & $\begin{array}{l}30 \% \\
81 \% \\
\end{array}$ & $\begin{array}{l}15 \text { capstone } \\
\text { design }\end{array}$ & & \\
\hline 8. Sustainability & $21 \%$ & & & 1: a deficiency \\
\hline $\begin{array}{l}\text { 9. Multimedia } \\
\text { breadth/interaction }\end{array}$ & $67 \%$ & & & \\
\hline 10. Societal impact & $32 \%$ & & & \\
\hline $\begin{array}{l}\text { 11. Contemporary } \\
\text { Global Issues }\end{array}$ & $23 \%$ & & & \\
\hline 12. teamwork & $88 \%$ & & & \\
\hline $\begin{array}{l}\text { 13. Professional and } \\
\text { ethical } \\
\text { responsibilities }\end{array}$ & $79 \%$ & & & \\
\hline 14. Communication & $81 \%$ & 2 writing & & $\begin{array}{l}\text { 7: should be more } \\
\text { emphasis }\end{array}$ \\
\hline 15. Lifelong learning & $12 \%$ & & & \\
\hline $\begin{array}{l}16 . \text { Project } \\
\text { management }\end{array}$ & $32 \%$ & & & \\
\hline $\begin{array}{l}\text { 17. Business and } \\
\text { public administration }\end{array}$ & $39 \%$ & & & \\
\hline 18. Leadership & $25 \%$ & & & \\
\hline
\end{tabular}

Table 6 also summarizes the percentage of the students in the first-year course that discussed the various BOK outcome areas in their final reflective essays in 2008. The underlined term in the first column of Table 6 indicates the keyword that was used to code the student essays. It is 
interesting that at least some of the 57 students touched on all of the EnvE BOK outcomes. The most widely cited aspects were Outcome 1 math and science, Outcome 12 teamwork, Outcome 7 design, and Outcome 14 communication. Therefore, the combination of guest speakers and activities in the first year course indicated to the students that skills in these areas were important to EnvE. It is gratifying that all of these areas resonated with at least some of the students.

\section{Alumni Perspectives on the EnvE BOK Knowledge Domains}

Table 7 summarizes the number of required courses in our curriculum that map to the various EnvE BOK knowledge domains. The number of the 31 alumni who responded to the survey in $2005-2008$ and wrote in comments in relation to each area are also shown. The existing EnvE B.S. curriculum at the University of Colorado at Boulder covers 13 of the 16 EnvE BOK knowledge domains with one or more required courses. A single course covers economics and systems analysis. No single course explicitly covers business management, but this material is included in the capstone design course.

Table 7. Coverage of EnvE Knowledge Domains in the Curriculum and Importance Noted by Alumni based on their Write-In Comments

\begin{tabular}{|c|c|c|c|c|}
\hline \multirow[t]{2}{*}{ Knowledge Domain } & \multirow{2}{*}{$\begin{array}{c}\text { \# } \\
\text { required } \\
\text { course }(\mathrm{s})\end{array}$} & \multicolumn{3}{|c|}{$\begin{array}{l}\text { Alumni Survey Write-In Comments, \# individuals: related } \\
\text { courses or information }\end{array}$} \\
\hline & & Most helpful & Least helpful & Deficiency/improve \\
\hline $\begin{array}{l}\text { Math, computer } \\
\text { languages }\end{array}$ & 5 & & $\begin{array}{l}\text { 3: numerical mth; } \\
\text { 1: calculus; } \\
\text { 6: computing on } \\
\text { wrong languages }\end{array}$ & $\begin{array}{l}\text { 3: wished they had } \\
\text { learned more } \\
\text { computing in Excel }\end{array}$ \\
\hline Physics, Mechanics & 3 & & $\begin{array}{l}\text { 1: physics lab } \\
\text { 1: statics }\end{array}$ & \\
\hline Chemistry & 5 & $\begin{array}{l}\text { 8: water } \\
\text { chemistry lab }\end{array}$ & $\begin{array}{l}\text { 4: physical } \\
\text { chemistry }\end{array}$ & \\
\hline Biology and Ecology & 1 & 5: microbiology & 1: ecology & $\begin{array}{l}\text { 1: more biol/ ecol } \\
\text { should be included }\end{array}$ \\
\hline Mass Conservation & 1 & \multirow{2}{*}{$\begin{array}{l}\text { 3: matl \& } \\
\text { energy balances }\end{array}$} & & \\
\hline Energy Conservation & 1.5 & & & \\
\hline Mass transport & 1 & & & \\
\hline Heat transport & 1 & & 3 & \\
\hline Fluid mechanics & 1 & 1 & 2: poor instructor & \\
\hline Earth Science & 1 & & & 2: more needed \\
\hline Systems Analysis & 0.5 & & & \\
\hline $\begin{array}{l}\text { Probability and } \\
\text { Statistics }\end{array}$ & 1 & 2 & & \\
\hline Humanities \& SS & 5 & & & \\
\hline Economics & 0.5 & & & 2: should be req'd \\
\hline Tech. Communication & 1 & 2: writing & & $\begin{array}{l}\text { 7: should be more } \\
\text { emphasis }\end{array}$ \\
\hline Business Management & NA & & & \\
\hline
\end{tabular}

$\mathrm{NA}=$ not asked in alumni survey 
The alumni comments highlight aspects in our curriculum they have found most beneficial and least beneficial in their careers, and recommend areas for improvement. Some courses were stated as being beneficial due to a significant writing component. For example, some of the 8 who mentioned that water chemistry lab was the most helpful elaborated by indicating that the extensive written reports were useful. The negative comments pertaining to fluid mechanics were both noted to be driven by the quality of the course specific to our University rather than the importance of the content to the EnvE profession.

The negative course stand-outs are physical chemistry and heat transfer. The BOK only notes chemistry proficiency, so our five courses in this area may be excessive. Heat transfer is a required course in both mechanical and chemical engineering, and reflecting the links of our profession and our faculty to this area it is a requirement in our EnvE degree. Numerical methods was removed as a required course in the curriculum starting in fall 2006. The deficiency noted in economics was remediated by adding the required economics/systems analysis course starting in fall 2004; however many of the alumni who were surveyed went through our program before this change. Of all the knowledge domain areas in the BOK only heat transfer has been identified by our alumni as unimportant. However, the noted deficiencies here and in Table 6 (communication, CAD, GIS, earth science, sustainability) may be difficult to incorporate while still fulfilling all of the BOK outcome and knowledge domain topics to the level of achievement specified.

\section{Overly Constrained}

Overall, a big concern with the BOK is that it is overly constrained. Due to the variety of career paths, cramming all possible topics that one might need to know into the B.S. degree seems unrealistic. Over constraint that leads to a loss of flexibility also turns off some students. Three of the students in the 2008 first-year class who stated that they were planning to change their major out of engineering commented that a big reason for their decision was that the EnvE major was overly restrictive. An example quote from one essay is particularly telling:

...in all honesty, I really do love the Environmental Engineering profession. The possibility of me traveling and helping communities in need sounds absolutely amazing. [but] After signing up for classes, and seeing my pre-planned schedule for the next four to five years, I soon realized this school was not for me. Initially, I viewed college as a learning experience, trying everything you can get your hands on to eventually find what you truly love, but I find that this engineering program does not let you do that. The Environmental Engineering program still interests me intensely, but I also want to try Shakespeare, religious studies, and philosophy courses not possible to take if I want to graduate in four years.

Another student writes:

After my first semester in the college of engineering and applied sciences, I have concluded that I am not meant to be an engineer. I feel I can help mankind and the environment in other ways, I do not strictly have to be an engineer in order to do this. Environmental engineering is a very ... interesting form of engineering. The prevalent idea of working to change the state of the environment makes this very appealing to me. The involvement of morals and ethics 
within the profession is globally significant and inspiring. [but] After seeing the kinds of classes I would have to endure it became apparent that I most likely wouldn't be able to accomplish all this in four years, an experience which I don't particularly feel I would enjoy.

So here the students appear truly interested in the profession after learning about it for an entire semester. But they want to be more well-rounded and have a broad learning experience that did not appear possible after completing the homework assignment where the students mapped a course plan to graduation. This reflects what Dom Grasso terms the need for engineering to be a "liberal education", not just a narrowly focused technical / vocational discipline. ${ }^{9}$ Our curriculum does fulfill the bulk of the BOK requirements. But at what cost? We only have 15 credits of humanities and social science electives in our program, and these must be on a list approved by the College of Engineering. We only have 12 technical elective credits, and even those are constrained to require the inclusion of an Earth Science course and 9 credits must be upper division. There are no free electives in our curriculum of 128 semester credits. This truly is a daunting prospect to some students.

As a licensed P.E. in environmental engineering with a B.S. degree in Civil Engineering, I did not have bachelor's level coursework that covered all of the topics on the EnvE BOK outcome and knowledge domain lists. The process of cramming more and more technical breadth and depth into the bachelor's degree level may actually work against acquisition of the variety of "soft skills" that are also so important to ultimate success in our profession. Interestingly, all of the students that stated an intent to leave the EnvE major were also interested in engineering to serve the developing world. It is tragic that we may be losing students from environmental engineering who could ultimately have the greatest impact on our world because of the appearance of inflexibility and a weed-out mentality that persists in most engineering curricula.

One student writes: "It takes a lot of hard work and determination to become an engineer. Engineers make a huge difference in the world and are very important aspects to our everyday lives. ...the global opportunities that can arise from environmental engineering, for example Engineers Without Borders, appeals to me greatly. While I would like to be held at such regards, I have to be honest with myself. I am not the right type of person for engineering and need to apply myself to another field, that can hopefully make as much of a difference in the world as engineers."

The guest speakers in the class who were practicing environmental engineers were asked what courses were most important to their current success. One answered: "communication" and "learning to think". That is pretty broad. Not a laundry list of aptitudes. If we truly give our students the ability to learn on their own and think critically, this will be their greatest strength in an ever evolving world that will place unknowable demands on our profession.

\section{Recruiting Students into EnvE}

In the first year Civil Engineering course at CU, some students commented that they found the Civil Engineering BOK inspiring. So a well-written BOK might help attract and retain students in the major. However, the EnvE students did not show a similar response to the draft EnvE BOK. For example, in the first year EnvE course, energy was the primary self-reported interest 
area of $26 \%$ and $35 \%$ of the students in 2007 and 2008, respectively. However, the role of environmental engineers in energy was not emphasized in the draft EnvE BOK. It was noticeably absent from the examples of traditional areas of competence or the emerging areas of specialization. The word "energy" appeared only 19 times in the draft EnvE BOK ${ }^{1}$, primarily in reference to material and energy balances and sustainability/life cycle assessment. Students passionate about this area may read the EnvE BOK and feel that this isn't an appropriate major for their interest despite the significant waste-to-energy and lifecycle assessment opportunities for which EnvE's are best qualified. The revised final $\mathrm{BOK}^{8}$ now states that design for energy is an emerging area. This increased emphasis on energy will be of benefit in recruiting and retaining these students in EnvE.

The draft EnvE BOK did not appear to capture student interest. For example, the students in the first year course were explicitly asked to discuss three skills or abilities that are unique to environmental engineering and distinguish it from other engineering majors. They were referred to the ABET major-specific criteria and the EnvE BOK to find this information. Very few identified the items that most EnvE professors or professionals would probably list (such as multimedia interactions, systems analysis, etc.). Sustainability was the most common response from the students that mirrored the BOK outcomes. Sustainability was mentioned by 15 of the 60 students on homework 1. Most of the students cited information that originated from ABET rather than the BOK. Thus, the BOK information may have been too dense or confusing to help them answer the question. It is hoped that the new final BOK will be more inspiring.

\section{Summary and Concluding Remarks}

The EnvE BOK represents a significant advance in defining the field of environmental engineering and the expectations of skills that professionals will obtain. The task force of writers representing a diverse range of professionals and academics clearly devoted significant effort into developing a document that represents an ideal that programs can aspire to achieve. The EnvE curriculum at our university appears to currently cover almost all of the outcomes and knowledge domains specified in the draft EnvE BOK. Required courses can be mapped to all of the knowledge domains except business management. This area is covered to some degree in our capstone design course. The EnvE curriculum at $\mathrm{CU}$ also appears to cover all of the outcomes to at least some extent. However, documentation of the levels of achievement in each outcome area is more complex and has not yet been completed. The concern is that the work needed to document and prove the achievement of these outcome levels in all courses in the curriculum would be overly burdensome in terms of both time and monetary resources, to the extent that our university would not be able to comply.

A method to selectively illustrate these levels of achievement across the entire curriculum for individual students would probably need to shift to a portfolio-based approach. This would shift some of the outcomes documentation burden from faculty to students. The students would be required to document their learning in the portfolios, and these would be reviewed by faculty prior to graduation. The student could potentially benefit from the portfolio by using it for job interviews. The question becomes what happens if students did not document sufficient knowledge? They could be given extra coaching to find such examples or be required to take extra courses to gain the necessary level of knowledge. This portfolio approach also appears 
difficult, time consuming, and subject to individual interpretation. More discussion will be needed with our faculty, professional advisory board, and students to determine the best way to tackle the challenges posed by the EnvE BOK in its present form. It is hoped that the AAEE will allow a mechanism to report feedback and consider BOK revision in the future if the collective voice of the academic community indicates that the present BOK presents unacceptable burdens.

Students in a first-year introductory EnvE course were introduced to the Body of Knowledge on the first homework assignment. In open-ended reflective essays that they wrote at the end of the semester, they included comments the revealed familiarity and recognition of all $18 \mathrm{BOK}$ outcomes in some fashion. The most highly represented themes in their essays included science, teamwork, math, and communication, along with the sub-discipline/media areas of water and air. Alumni of our program practicing as EnvE professionals gave open-ended comments on a written survey that indicated that some of the topics on the knowledge domain list were nonessential, such as heat transfer, while other more general skills such as communication were essential. The fear is that the long list of requirements for both outcomes and knowledge domains in the current EnvE BOK will overly constrain our programs and drive us to cram in more information at the detriment of developing broader skills in our students. A curriculum that fully fulfills the requirements of the EnvE BOK may also drive away students who have the potential to become the type of environmental engineers that our profession and our world desperately need.

\section{Bibliography}

1. AAEE. 2008. Draft Environmental Engineering Body of Knowledge. American Academy of Environmental Engineers. www.cecs.ucf.edu/bok/publications.htm, accessed June 2008.

2. Daggett, Willard R. 2005. Achieving Academic Excellence through Rigor and Relevance. International Center for Leadership in Education. 5 pp. http://www.leadered.com/pdf/Academic_Excellence.pdf, accessed Jan. 2009.

3. ASCE. 2008. Civil Engineering Body of Knowledge for the $21^{\text {st }}$ Century: Preparing the Civil Engineer for the Future. Second Edition. American Society of Civil Engineers. www.asce.org.

4. ABET. 2007. Criteria for Accrediting Engineering Programs. Effective for Evaluations During the 2008-2009 Accreditation Cycle. ABET Engineering Accreditation Commission. www.abet.org

5. Russell, J., G. Galloway, T. Lenox, and J.J. O’Brien. 2008. ASCE Policy 465 - Progress and Next Steps. ASEE Annual Conference \& Exposition. AC 2008-46.

6. Kilduff, J. 2007. Workshop: Frontiers in Environmental Engineering Education. Arizona State University, Tempe, AZ, Jan. 8-10. http://www.rpi.edu/ kilduff/NSF\%20Environ\%20Eng\%20Education\%20Workshop/Attendee\%20Info/Attendee\% 20package.pdf

7. Association of Environmental Engineering and Science Professors (AEESP) Board of Directors (J. Mihelcic, President). 2008. Letter to Debra Reinhart and C. Robert Baillod, EnvE BOK Committee Co-Chairs, American Academy of Environmental Engineering. http://www.aeesp.org/docs/AEESP_Comments_EEN_BOK_July_18.pdf

8. AAEE. 2009. Environmental Engineering Body of Knowledge. American Academy of Environmental Engineers. The Environmental Engineering Body of Knowledge Task Force. January. http://www.cece.ucf.edu/bok/pdf/EnvE_Body_of_Knowledge_Final.pdf, accessed March 2009.

9. Grasso, Domenico. 2002. Engineering a Liberal Education. Prism, 12 (2), 76. http://www.prismmagazine.org/nov02/lastword.cfm

10. ABET. Accredited Programs by Disciplinary Area: Environmental. List of programs accredited as of Oct. 1, 2008. Accessed March 20, 2009. http://www.abet.org/schoolarea.asp 